\title{
SALEZJAŃSKI WOTYWNY KOŚCIÓŁ MATKI BOŻEJ OSTROBRAMSKIEJ WE LWOWIE. HISTORIA I DZIEŃ DZISIEJSZY
}

Pierwsza wojna światowa, konflikt światowy o charakterze wojny totalnej, zmieniła diametralnie układ sił politycznych w Europie. Doprowadziła do upadku czterech najpotężniejszych kontynentalnych mocarstw - Austro-Węgier, Turcji, Niemiec i Rosji - oraz umożliwiła powstanie wielu nowych narodowych państw w Europie Środkowej: Czechosłowacji, Węgier, państw bałtyckich i największego - Polski, która po ponadwiekowej niewoli odzyskała niepodległość, ale jeszcze przez najbliższe lata musiała zmagać się militarnie o ustalenie swych granic $^{1}$.

$\mathrm{Na}$ ten burzliwy okres przypadają rządy archidiecezją lwowską ostatniego prymasa Galicji abpa Józefa Bilczewskiego². W latach 1900-1922 pasterz tej diecezji konsekwentnie realizował program ożywienia różnych form duszpasterstwa, tworzył nowe parafie obrządku łacińskiego i budował kościoły. W ten sposób zapobiegał wynarodowieniu ludności polskiej, w tym głównie na wsi. W okresie

* Ks. Waldemar Witold Żurek - dr hab. historii Kościoła, prof. KUL, Dyrektor Ośrodka Archiwów Bibliotek i Muzeów Kościelnych KUL, e-mail: zurek@kul.pl

${ }^{1}$ J. Prokopczuk, Historia powszechna 1871-1939, Warszawa 1984, s. 148-152.

2 Józef Bilczewski (1860-1923) - po święceniach kapłańskich w 1884 roku i studiach specjalistycznych za granicą pracował w duszpasterstwie w diecezji krakowskiej, a po habilitacji w 1890 roku na Uniwersytecie Jagiellońskim, następnie na Uniwersytecie Lwowskim. W 1900 roku mianowany został ordynariuszem lwowskim. Przyczynił się do zwiększenia liczby powołań kapłańskich i liczby parafii oraz do podniesienia poziomu nauczania religii, zwłaszcza katechizacji. U papieża Piusa X wyjednał pozwolenie na obchodzenie święta Królowej Korony Polskiej w swej archidiecezji, później rozszerzone na inne diecezje polskie. Zainicjował wydawanie czasopism kościelnych. W listach pasterskich abp Bilczewski obok spraw duszpasterskich wyjaśniał podstawowe zasady życia społecznego, akcentując chrześcijański pogląd na osobę ludzką, rodzinę i państwo. Prowadził szeroką działalność społeczną, popierał stowarzyszenia robotnicze, troszczył się o duszpasterzy dla polskiej emigracji zarobkowej. Łagodził konflikty narodowościowe w archidiecezji. Pozostawił bogaty dorobek naukowy. Kanonizowany w 2005 roku w Rzymie. Zob. R. Dzwonkowski, Bilczewski Józef, w: Encyklopedia katolicka (dalej: EK), t. 2, Lublin 1976, kol. 558-559. 
23-letnich rządów arcybiskup erygował 21 parafii, 96 ekspozytur, 328 kościołów filialnych i kaplic. Zabiegał, by w jego archidiecezji zakony podejmowały pracę zgodnie ze swoim charyzmatem. Przyczynił się do erygowania 7 domów zakonnych męskich i 135 domów żeńskich, w których pracowało łącznie prawie tysiąc zakonników i zakonnic ${ }^{3}$.

\section{Geneza budowy kościoła Matki Bożej Ostrobramskiej we Lwowie}

Wraz z rozwojem Lwowa i urzeczywistnieniem planu tzw. wielkiego Lwowa zaistniała konieczność objęcia opieką duszpasterską rozbudowujących się przedmieść i terenów podmiejskich. Intencją abpa Bilczewskiego i jego następcy abpa Bolesława Twardowskiego ${ }^{4}$ było stworzenie sieci parafii podmiejskich ${ }^{5}$. Szczególna potrzeba budowy nowego kościoła i utworzenia ośrodka duszpasterskiego istniała na Górnym Łyczakowie, gdzie w 1785 roku rząd zaborczy pozbawił mieszkańców własnego kościoła (kościół św. Piotra i Pawła przekazany został grekokatolikom, obecnie jest cerkwią prawosławną, ul. Łyczakowska 82a). Od tego czasu wierni tej dzielnicy należeli do parafii św. Antoniego ${ }^{6}$, której niewielka

\footnotetext{
${ }^{3}$ Bilczewski Józef, w: Polski Słownik Biograficzny, t. 2, Kraków 1936, s. 94.

${ }^{4}$ Abp Bolesław Twardowski (1854-1944) - biskup pomocniczy lwowski 1918-1923, arcybiskup metropolita lwowski w latach 1923-1944. Po święceniach kapłańskich w 1886 roku studiował prawo kanoniczne na Gregorianum, gdzie zaprzyjaźnił się z ks. Józefem Bilczewskim. Po uzyskaniu doktoratu pracował w lwowskim seminarium duchownym, w lwowskiej kurii metropolitalnej i w duszpasterstwie. W 1918 roku mianowany został biskupem pomocniczym archidiecezji lwowskiej. Po śmierci abpa Bilczewskiego otrzymał w 1923 roku bullę nominacyjną na arcybiskupstwo lwowskie. Jego troską było zwiększenie sieci parafialnej w archidiecezji. Największym osiągnięciem na polu budownictwa sakralnego było wybudowanie kościoła Matki Boskiej Ostrobramskiej jako wotum za utrzymanie Kresów przy Macierzy, w tym za powrót Lwowa do Ojczyzny. Był inicjatorem budowy świątywni wotywnej i fundatorem całego przedsięwzięcia. Był propagatorem idei Akcji Katolickiej i charytatywnej działalności Kościoła. W czasie kryzysu ekonomicznego w latach trzydziestych ubiegłego wieku aktywnie angażował się na rzecz zwalczania bezrobocia i głodu w archidiecezji lwowskiej. Był przeciwnikiem czynnej akcji politycznej duchownych. W swej posłudze pasterskiej utrzymywał i pomnażał polskie wartości narodowe i chrześcijańskie na kresach archidiecezji. W czasie II wojny światowej apelował m.in. do abpa Andrzeja Szeptyckiego o zahamowanie zbrodni ukraińskich na polskiej ludności cywilnej. Pochowany został w krypcie kościoła Matki Boskiej Ostrobramskiej, a serce umieszczono w ścianie chóru zakonnego klasztoru sióstr karmelitanek we Lwowie. Po sprofanowaniu kościoła na Łyczakowie przez Sowietów zwłoki abpa Twardowskiego przeniesiono (1947/1948) do krypty w podziemiach bazyliki metropolitalnej we Lwowie. Serce metropolity siostry karmelitanki wywiozły po wojnie do Włocławka. Zob. G. Chajko, Arcybiskup Bolestaw Twardowski (1864-1944). Metropolita lwowski obrządku tacińskiego, Rzeszów 2010.

${ }^{5}$ Abp Twardowski zabiegał o rozbudowę sieci parafialnej w archidiecezji. Erygował 7 parafii, 26 ekspozytur i 214 kaplic. Za jego posługi wybudowano 27 kościołów. Opracował program budowy domów parafialnych. Zob. B. Modzelewska, W. Osadczy, Lwowska archidiecezja katolicka, EK, t. 11, Lublin 2005, kol. 271.

${ }^{6}$ Pierwszy drewniany kościół franciszkanów powstał tu w 1617 roku. W 1655 roku został poważnie zniszczony w czasie ostrzału kozackiego. Murowaną świątynię ufundował w 1669 roku książę Michał Wiśniowiecki, przebudowaną w 1718 roku. Barokowe fasady świątyni nadał w 1769 roku architekt Franciszek Kulczycki. Po II wojnie światowej franciszkanie przebywali w klasztorze
} 
świątynia przy ulicy Łyczakowskiej 49a nie zaspokajała potrzeb duchowych wiernych i stanowiła umowną granicę Dolnego i Górnego Łyczakowa. Aż do lat dwudziestych XX wieku kościół ten był jedyną katolicką świątynią Górnego Łyczakowa?.

Pierwszy Sejm II Rzeczypospolitej w dowód wdzięczności Bogu za przywróconą wolność i pamiętając o przyrzeczeniach przodków z okresu Sejmu Czteroletniego, zdecydował o budowie w Warszawie monumentalnej świątyni Opatrzności Bożej. Miało to być wotum za wybawienie narodu polskiego z półtorawiekowej niewoli. Za przykładem stolicy podejmowano lokalne inicjatywy budowania świątyń wotywnych ${ }^{8}$. We Lwowie metropolita Twardowski zainicjował budowę kościoła Matki Bożej Ostrobramskiej, jako symbolu wdzięczności Lwowa i Małopolski Wschodniej za powrót na łono odrodzonej ojczyzny po zaborczej niewoli, po niezliczonych ofiarach krwi i mienia złożonych w walkach w latach 1918-19209. Inicjatywa ta została podjęta przez władze miasta i mieszkańców. Zgodnie z racjami władz miejskich i prośbami mieszkańców Górnego Łyczakowa na miejsce przyszłej świątyni wybrano wschodnią część miasta - Górny Łyczaków. Teren pod budowę znajdował się w czwartej dzielnicy na krańcach miasta, na stoku wzgórza pochylonego w kierunku centrum, w sąsiedztwie dawnej rogatki miejskiej i parku im. Bartosza Głowackiego. Na terenie tej podmiejskiej dzielnicy znajdowała się stacja kolejowa Lwów-Łyczaków i koszary Pułku Ułanów Jazłowieckich ${ }^{10}$. Tuż za stacją kolejową rozciągała się bogatsza dzielnica willowa tzw. Profesorówka. Górny Łyczaków zamieszkiwała w większości ludność uboga, pozbawiona wodociągów i kanalizacji. Plan tzw. wielkiego Lwowa uwzględniał włączenie do miasta gmin podmiejskich i rozbudowę Górnego Łyczakowa ${ }^{11}$.

lwowskim do 25 IV 1946, po czym musieli opuścić go pod naciskiem komunistycznej władzy. Kościół św. Antoniego pozostał, obok katedry lwowskiej, jedynym rzymskokatolickim kościołem lwowskim nieprzerwanie czynnym do dziś. Jedynym zakonnikiem, który zdecydował się pozostać we Lwowie, był o. Rafał Kiernicki (1912-1995), więzień łagrów komunistycznych, duszpasterz i proboszcz katolickiej katedry we Lwowie, od 16 I 1991 roku biskup. W 1989 roku przybyli do Lwowa franciszkanie z Polski i zamieszkali przy swoim dawnym kościele św. Antoniego gdzie podjęli posługę duszpasterską. Zob. B. Kaczorowski, Zabytki starego Lwowa, Warszawa 1990.

${ }^{7}$ A. Medyński, Kościót Matki Boskiej Ostrobramskiej na Łyczakowie, Lwów 1938, s. 6.

${ }^{8}$ Poznań wzniósł pomnik Chrystusa Króla, Pomorze podjęło myśl budowy bazyliki morskiej, Kowel na Wołyniu wystąpił ze świątynią wotywną jako dziękczynne wotum. Zob. tamże, s. 3-4.

${ }^{9}$ Archiwum Salezjańskiej Inspektorii Krakowskiej, A 97, Akt erekcyjny złożony w kamieniu węgielnym kościoła MB Ostrobramskiej we Lwowie; Chajko. Arcybiskup Bolesław Twardowski, s. 200; Medyński, Kościót Matki Boskiej Ostrobramskiej, s. 3-4.

${ }^{10}$ 14. Pułk Ułanów Jazłowieckich - oddział kawalerii Wojska Polskiego II Rzeczypospolitej. Z końcem czerwca 1919 roku pułk rozpoczął działania zbrojne w Małopolsce Wschodniej przeciwko oddziałom ukraińskim. W dniach 11-13 VII 1919 roku pułk w ciężkim boju pod Jazłowcem odparł atakujące oddziały ukraińskie i nie dopuścił wroga do klasztoru sióstr niepokalanek w Jazłowcu. Po tym wydarzeniu Najświętsza Maria Panna Jazłowiecka została patronką pułku, który przyjął nazwę „Jazłowiecki”. Po wyparciu wojsk ukraińskich za Zbrucz pułk przeszedł na Wołyń, by walczyć z bolszewikami. Numer „14” otrzymał w sierpniu 1919 roku wraz z oficjalnym zatwierdzeniem nazwy. Miejsce postoju: garnizon Lwów. Zob. Księga jazdy polskiej, Warszawa 1936. Reprint: Warszawa 1993.

${ }^{11}$ Chajko. Arcybiskup Bolestaw Twardowski, s. 200. 
Gmina miasta Lwowa uchwałą Rady Miejskiej pod przewodnictwem prezydenta Józefa Neumana z 11 i 18 VIII 1927 roku przekazała jako darowiznę kilka parceli gruntowych o powierzchni $4300 \mathrm{~m}^{2}$ i wartości 29887 złotych na własność planowanemu kościołowi pw. Najśwętszej Maryi Panny Ostrobramskiej, reprezentowanemu przez abpa lwowskiego ob. łac. Bolesława Twardowskiego. Sporządzony akt notarialny, podpisany przez komisarza rządu dra Ottona Nadolskiego i abpa Twardowskiego, wyszczególniał, że „fizyczne oddanie podmiotu darowizny nastąpi na każde żądanie kurii arcybiskupiej ob. łac., pod której zarządem kościół katolicki obrządku łacińskiego pod wezwaniem NMP Ostrobramskiej we Lwowie będzie pozostawał". Przekazanie stronie kościelnej darowizny nastąpiło 9 XI 1928 roku, a już dwa dni później odbyło się uroczyste poświęcenie gruntu i ustawienie na nim krzyża dla upamiętnienia 10. rocznicy odrodzenia Polski.

Metropolita lwowski i inicjator budowy kościoła planował stworzenie przy świątyni placówki o charakterze narodowym służącej katolickiemu społeczeństwu miasta. Najprawdopodobniej już wówczas kontaktował się listownie z ówczesnym prowincjałem (inspektorem) salezjanów polskich ks. Antonim Hlondem, przedstawiając Zgromadzeniu Salezjańskiemu ofertę przejęcia budowy kościoła i zakładu wychowawczego dla młodzieży. Intencją arcybiskupa było, aby już w roku beatyfikacji (1929) księdza Jana Bosko zgromadzenie równocześnie rozpoczęło budowę kościoła i zakładu. Przełożony polskiej Prowincji św. Stanisława Kostki ks. Antoni Hlond na przyjęcie oferty uzyskał zgodę przełożonego generalnego zgromadzenia w Turynie, który rok 1932 uznał za możliwy termin osiedlenia się salezjanów we Lwowie. Tę decyzję wymusiła trudna sytuacja finansowa prowincji polskiej i wcześniejsze zarządzenie przełożonych generalnych, aby $\mathrm{w}$ czteroletnim okresie 1928-1932 nie przyjmować nowych placówek ${ }^{12}$.

Dnia 19 II 1929 roku na posiedzeniu obywatelskim u arcybiskupa zdecydowano powołać Społeczny Komitet Budowy Kościoła na Górnym Łyczakowie, który ukonstytuowano 4 III 1929 roku pod protektoratem metropolity. W skład Komitetu weszli przedstawiciele mieszkańców Lwowa pod przewodnictwem dra Ottona Nadolskiego. Komitet przystąpił niezwłocznie do zbierania funduszy i przygotowania planów budowy. W posiedzeniach Komitetu Budowy uczestniczył okazjonalnie przełożony salezjańskiej placówki w Przemyślu na Zasaniu ks. Jan Świerc. To on w imieniu przełożonego prowincji przekazywał sugestie dotyczące głównie planów budowy przyszłego zakładu wychowawczego ${ }^{13}$.

Komitet Budowy Kościoła 19 IV 1929 roku rozpisał konkurs na plany budowy świątyni i zakładu młodzieżowego. Wykonanie projektów zaproponowano

${ }^{12}$ J. Krawiec, Powstanie Towarzystwa św. Franciszka Salezego oraz jego organizacja i działalność na ziemiach polskich, Kraków 2004, s. 151; A. Świda, Inspektorzy polskich prowincji, cz. 1, Warszawa 1989, s. 44; Salezjanie we Lwowie, „Pokłosie Salezjańskie”, 18 (1934) s. 230.

${ }^{13}$ Skład prezydium Komitetu Budowy Kościoła: ks. kanonik Walenty Dubiel (delegat kurii metropolitalnej), dyrektor Franciszek Bajon, dyrektor Emil Kwiatkowski, notariusz Wojciech Mayer, inż. Kazimierz Perier, dr Bruno Pokorny, Zofia Nadolska i Sewera Kwiatkowska z Koła Pań Sodalicji Mariańskiej. ASIK, Sygn. A 97, Komitet Budowy Kościoła na Górnym Łyczakowie we Lwowie pod wezwaniem Matki Boskiej Ostrobramskiej, Do Polaków-Katolików, Lwów, luty 1932, s. 1 (druk ulotny). 
sześciu architektom: trzem ze Lwowa, dwóm z Krakowa i jednemu z Warszawy. Wybrano projekt architekta lwowskiego profesora Politechniki dra Tadeusza Obmińskiego, o czym zdecydował powołany Sąd Konkursowy. W zasadniczej formie kościół zaprojektował dr Obmiński, a po jego śmierci kierownictwo architektoniczne przejął inż. Wawrzyniec Dayczak, absolwent Politechniki Lwowskiej i budowniczy wielu obiektów sakralnych. Po sporządzeniu i zatwierdzeniu planów rozpoczęto prace przygotowawcze pod kierownictwem architekta i pod technicznym nadzorem inż. Stefana Neuhoffa. Prace rozpoczęto dnia 8 VIII 1931 roku od wykopów pod fundamenty wieży, a w święto Matki Bożej Różańcowej 7 października tego roku abp Twardowski dokonał poświęcenia kamienia węgielnego przy bardzo licznym udziale lwowian. W ceremonii tej uczestniczył abp obrządku ormiańskiego Józef Teodorowicz i bp pomocniczy Franciszek Lisowski ${ }^{14}$.

Wkrótce okazało się, że parcela pod inwestycje budowlane jest niewystarczająca dla planowanego zakładu młodzieżowego, ze względu na brak terenu na zaplecze rekreacyjno-sportowe. W czasie wizyty we Lwowie ówczesny ksiądz inspektor Antoni Symior sugerował kupno przyległego do placu kościelnego gruntu o powierzchni 850 sążni. Komitet Budowy kupił wspomniany teren za cenę 9 tysięcy dolarów, a stosowny akt kupna podpisano $19 \mathrm{~V} 1931$ roku u notariusza lwowskiego Wojciecha Mayera ${ }^{15}$. Zdaniem fachowców zakup był korzystny. Po transakcji zakupu dodatkowego gruntu arcybiskup zwrócił się do salezjanów o zwrot należności za nabycie gruntu. To rozpoczęło trwającą prawie do zakończenia budowy kościoła kłopotliwą dla obu stron kontrowersję. Arcybiskup twierdził, że zgromadzenie winno zapłacić za nabytą parcelę, skoro jego przełożeni przyjęli zobowiązanie budowy zakładu. Z kolei inspektor Antoni Symior z powodu braku środków nie mógł zwrócić żądanej należności, mimo że uznawał słuszność i potrzebę zakupu dodatkowej parceli ${ }^{16}$.

Na dokupionym placu stał dom, który częściowo (2 pokoje) wyremontowano dla potrzeb budowy. W połowie września 1931 roku arcybiskup sugerował salezjanom odrestaurowanie pozostałej jego części (4 pokoje), zamieszkanie w nim jednego salezjanina i podjęcie pracy duszpasterskiej. W sąsiedztwie bowiem stała

${ }^{14} \mathrm{~W}$ kazaniu abp Twardowski przedstawił potrzebę budowy kościoła, jako bramy strzegącej miasto przed inwazją ukraińską z lat 1918-1919 i bolszewicką z roku 1920. Zob. W.W. Żurek, Oddziaływanie duszpasterskie salezjanów w Kościele katolickim na Ukrainie, „Archiwa Biblioteki i Muzea Kościelne" (dalej: ABMK), 85 (2006) s. 408-409; Medyński, Kościót Matki Boskiej Ostrobramskiej, s. 8-9.

${ }^{15} \mathrm{Na}$ początek wypłacono sumę 3 tysięcy dolarów z funduszów budowy kościoła. Pozostałą sumę zobowiązano się wypłacić do 1 VIII 1931 roku. Zob. S. Rozner, W.W. Żurek, Salezjanie we Lwowie w latach 1934-1945, ABMK, 68 (1997) s. 373.

${ }^{16}$ Początkowo wydawało się, że wybudowanie kościoła i zakładu będzie możliwe na posiadanym już gruncie. Nie ma dokumentu potwierdzającego, że salezjanie kupią plac pod budowę zakładu. Arcybiskup sądził, że w dwa lata salezjanie zbiorą milion złotych i wybudują obok kościoła duży zakład. Na nalegania arcybiskupa o zwrot kosztów zakupu dodatkowej parceli inspektor odpowiadał pozytywnie, jednak nie określał terminu ani wysokości sumy, ani nawet raty zwrotu należności. W liście z 1931 roku abp Twardowski pisał do przełożonego prowincji: „Gdybym był przypuszczał, że mogę taką odpowiedź otrzymać, nigdy bym nie rozpoczynał budowy kościoła”. Zob. Rozner, Żurek, Salezjanie we Lwowie, s. 373. 
drewniana kaplica Matki Boskiej Ostrobramskiej, w której niedzielną Mszę Świętą i wieczorne błogosławieństwo odprawiał ks. infułat Wincenty Czajkowski. Ze względu na rozpoczęty już rok szkolny 1931/1932 sprawę tę odłożono do wiosny przyszłego roku. W lutym 1932 roku arcybiskup, informując o planach budowy, zakładał na ten rok wydatki przynajmniej 500 tysięcy złotych, a przełożony prowincji salezjańskiej dysponował na razie kilkudziesięcioma tysiącami. Przypomnijmy, że był to czas jednego z największych kryzysów finansowych na świecie. $\mathrm{O}$ fatalnym stanie polskiej prowincji salezjańskiej, załamaniu się wielu przedsięwzięć i o niemożliwości spłaty długu informował arcybiskupa ksiądz inspektor.

Na 27 VII 1932 roku został wyznaczony przyjazd na stałe do Lwowa pierwszego salezjanina ks. Alojzego Golubskiego, byłego przełożonego (u salezjanów dyrektora) Zakładu Serca Jezusowego w Wilnie przy ul. Dobrej Rady 22. Dwa dni przed jego przyjazdem abp Twardowski ten termin przesunął na później. W liście z 26 VIII 1932 roku thumaczył księdzu inspektorowi, że dzień przybycia salezjanina do Lwowa do pracy uważa za bardzo ważny dla archidiecezji i miasta. Mimo że przybywa tylko jeden kapłan, pasterz diecezji winien go wprowadzić, zebranym przedstawić i rozpoczęcie dzieła pobłogosławić. Powrót do Lwowa arcybiskup planował dopiero pod koniec września i wówczas w tej sprawie miał się porozumieć $\mathrm{z}$ inspektorem ${ }^{17}$.

Do zimy 1932 roku zakładano podciągnąć mury kościelne pod dach, położyć sufit bazylikowy i całość pokryć dachem. Według szacunków inżyniera nadzoru budowy Neuhoffa na te prace potrzebowano przynajmniej pół miliona złotych. W lecie 1932 roku arcybiskup otrzymał od prowincjała salezjanów jedynie kwotę 5 tysięcy złotych. Przy tej okazji nie omieszkał nadmienić, iż dopraszanie się od wielu miesięcy o zwrot należności za dokupioną działkę jest dla niego wielkim upokorzeniem, chociaż wie, ,że dzisiaj trudno o pieniądze”. Tymczasem do 1 VIII 1932 roku na budowie wyczerpano wszystkie środki finansowe. Nadto na materiały budowlane wydano 9 tysięcy złotych, a w październiku tego roku zaciągnięto pożyczkę 20 tysięcy złotych, aby móc kontynuować prace budowlane. W sierpniu 1932 roku inspektor Symior poważnie zachorował, a jego obowiązki przejął radca inspektorialny ks. Tomasz Kopa, który na pisma arcybiskupa nie odpowiadał. Z listu arcybiskupa do dyrektora zakładu w Przemyślu ks. Jana Świerca dowiadujemy się, że spłata 9 tysięcy dolarów wraz z opłatami stempli notarialnych zapłacona przez Komitet Budowy to kwota 83 362,75 złotych. Do dnia 22 VII 1933 roku na poczet tej kwoty złożono sumę 44 019,40 zł, w tym salezjanie wpłacili 25 tysięcy złotych. Z pozostałej do wyrównania kwoty 38 343,35 zł arcybiskup oczekiwał zwrotu 20 tysięcy złotych, a resztę darował. Ostatecznie inspektor Symior prosił ks. Świerca z Przemyśla o przeznaczenie na spłatę długu spodziewanych wpływów ze spadków lub zaciągnięcie pożyczki. Sprawę pogarszał fakt, że oczekiwana pomoc od współbraci z Ameryki (m.in. kwesta ks. Szymona Majchera w Ramsey) okazała się niewystarczająca ${ }^{18}$.

Pomimo trudności w uzyskaniu koniecznych funduszy prace budowlane przy

${ }^{17}$ Tamże, s. 375.

${ }^{18}$ A. Świda, Towarzystwo Salezjańskie. Rys historyczny, Kraków 1984, s. 140, 146; tenże, Inspektorzy polskich prowincji, s. 45-48. 
kościele były realizowane w zaplanowanym tempie na kredyt. Wielką pomocą była uchwała Rady Miasta o przydzielenie subwencji 250 tysięcy złotych, rozłożonej na 5 rat rocznych. Niestety, udało się zrealizować tylko ratę pierwszą. Gdy w maju 1934 roku rozpoczęto prace wykończeniowe w kościele, z powodu braku funduszy Komitet Budowy poprzez kanclerza kurii metropolitalnej ks. Zygmunta Hałuniewicza zwrócił się do salezjanów o przesłanie sumy 7 tysięcy złotych na założenie instalacji elektrycznej w kościele. Wprawdzie założenie instalacji można było przesunąć na później, ale wówczas konieczne byłoby kucie ścian i wkładanie przewodów pod tynk. I tym razem inspektor $19 \mathrm{~V} 1934$ roku podał powody niemożności przesłania tej sumy ${ }^{19}$.

Do jesieni 1934 roku planowano doprowadzenie budowy do takiego stanu, aby świątynia mogła być konsekrowana. Tę uroczystość zaplanowano na 7 października, w święto Matki Boskiej Różańcowej. Uroczystość rozpoczęła się w sobotę 6 października tego roku. Abp Twardowski w asyście dwóch plutonów 14. Pułku Ułanów Jazłowieckich przywiózł relikwie św. Stanisława Biskupa i Męczennika i św. Jozafata. Złożono je w ołtarzu głównym, po czym nastąpiła adoracja Najświętszego Sakramentu. Następnego dnia obrzędu konsekracji dokonał abp Twardowski w asyście bpa Eugeniusza Baziaka, kanoników Kapituły Metropolitalnej i duchowieństwa. Zgromadzenie Salezjańskie reprezentował przełożony Prowincji św. Jacka w Krakowie ks. Tomasz Kopa i ks. Jan Świerc, wyznaczony na dyrektora placówki lwowskiej. Licznie reprezentowane były władze miejskie, wojsko (kompania honorowa 40. Pułku Piechoty ze sztandarami i orkiestrą) i osobistości Lwowa ${ }^{20}$. Uroczystość zaszczyciły delegacje Strzelca, Sokoła IV, Gwiazdy, Skały, Towarzystwa Strzeleckiego oraz szereg organizacji religijnych, społecznych i wojskowych. Obrzędy konsekracyjne według liturgii rzymskiej trwały blisko trzy godziny. Kazanie wygłosił abp Twardowski, a sumę pontyfikalną odprawił bp Eugeniusz Baziak w asyście księży infułatów Wincentego Czajkowskiego i Józefa Zajchowskiego, księży prałatów i kanoników. W czasie liturgii śpiewał chór alumnów seminarium archidiecezjalnego pod dyrekcją prof. W. Adamca. Dla pozostających na zewnątrz świątyni wiernych Mszę Świętą odprawił w logi frontowej proboszcz parafii św. Antoniego ks. kanonik Walenty Dubiel. Liturgia zakończyła się nabożeństwem eucharystycznym i błogosławieństwem Najświętszym Sakramentem. Na zakończenie odśpiewano Te Deum. Po tych uroczystościach miało miejsce symboliczne oddanie kluczy kościoła salezjanom. Prawne dopełnienie tego aktu dokonało się tego samego dnia w rezydencji arcybiskupa. Wobec Kapituły Metropolitalnej i prezesa Komitetu Budowy dra Ottona Nadolskiego Zgromadzenie Salezjańskie (inspektor ks. Tomasz Kopa, dyrektor

${ }^{19}$ Rozner, Żurek, Salezjanie we Lwowie, s. 377.

${ }^{20}$ M.in. wicewojewoda Ludwik Sochański, starosta lwowski Czesław Eckhardt, zastępca starosty grodzkiego Kirschner, wiceprezydent miasta Franciszek Irzyk, rektor Politechniki Lwowskiej i prezes Komitetu Budowy Kościoła prof. Otto Nadolski, pułkownik Kunachowicz, podpułkownik Kruszyński, grono oficerów, kurator Okręgu Szkolnego Lwowskiego Jerzy Gadomski, prezes Izby Skarbowej Gregor, dyrektor poczty Moszor, były dyrektor kolei Prachtl-Morawiński, przedstawiciele Ligi Parafialnej przy kościele św. Antoniego wraz z ks. kan. Walentym Dubielem i dyr. Zawistowskim, członkowie Towarzystwa Przyjaciół Przedmieścia Łyczakowskiego. 
ks. Jan Świerc) przejęło od abpa Twardowskiego, głównego fundatora i budowniczego świątyni, w wieczyste posiadanie kościół i parcelę. Przekazanie wotywnej świątyni maryjnej salezjanom miało symboliczne znaczenie. Odbyło się w roku kanonizacji w Rzymie (1 IV 1934) ks. Jana Bosko przez papieża Piusa XI. W ołtarzu głównym umieszczony był obraz Matki Boskiej Ostrobramskiej namalowany w 1931 roku przez felicjankę s. Marię Tadeę (Michalina Firczyk). Świątynia posiadała boczne ołtarze św. Jana Bosko i św. Teresy od Dzieciątka Jezus oraz kaplicę Najświętszego Serca Pana Jezusa ${ }^{21}$.

Kościół Matki Boskiej Ostrobramskiej pełnił funkcję kościoła rektoralnego na terenie parafii św. Antoniego. Brak jest dokumentu jednoznacznie stwierdzającego status prawny tego kościoła. Była to placówka niezależna od parafii w sprawach finansowych, jednak w sprawach duszpasterskich jej podlegała.

\section{Salezjańska działalność pastoralna na Górnym Łyczakowie}

Jeszcze przed konsekracją świątyni przełożony prowincji św. Jacka ks. Tomasz Kopa rozpoczął u abpa Twardowskiego starania o otwarcie na Górnym Łyczakowie domu zakonnego, na co arcybiskup 10 VIII 1934 roku wyraził pisemną zgodę. Po otrzymaniu pozytywnej odpowiedzi Kongregacji Zakonów z 25 IX 1934 roku generał zgromadzenia ks. Piotr Ricaldone erygował dekretem z 1 X 1934 roku dom zakonny pw. Matki Boskiej Ostrobramskiej we Lwowie, którego przełożonym został ks. Jan Świerc. Dyrektorzy tego domu byli równocześnie rektorami kościoła, z wyjątkiem okresu od kwietnia 1940 do lata 1943 roku, kiedy te funkcje były rozdzielone ${ }^{22}$. Placówka salezjańska we Lwowie należała po polskiej Prowincji św. Jacka z siedzibą prowincjała w Krakowie.

W duszpasterstwie parafialnym i w pracy z młodzieżą pomagali inni salezjanie. Kapłani uczyli religii w szkołach miejskich, prowadzili oratorium młodzieżo$\mathrm{we}^{23}$ oraz pomagali w pracy parafialnej. W sumie pracowało we Lwowie $10 \mathrm{kapła-}$ nów w tym domu i w kościele. W pracach tego domu pomagali bracia zakonni, zwani koadiutorami, których w latach 1934-1946 w tej placówce pracowało 9. Ci pełnili funkcje administracyjne i wykonywali prace służebne.

W duszpasterstwie salezjanów na Górnym Łyczakowie można wyróżnić duszpasterstwo ogólne związane z szafarstwem sakramentalnym, nauczaniem prawd wiary, kultem Matki Najświętszej i świętych oraz działalnością bractw i

${ }^{21}$ Krawiec, Powstanie Towarzystwa św. Franciszka Salezego, s. 151; Medyński, Kościót Matki Boskiej Ostrobramskiej, s. 24-27; Salezjanie we Lwowie, „Pokłosie Salezjańskie”, 8 (1934) s. 229234.

${ }^{22}$ Księża dyrektorzy: Jan Świec 1934-1936 (dyrektor i rektor), Antoni Guzik 1936-1940 (dyrektor i rektor), Sylwester Król 1940-1943 (dyrektor), Jan Symior 1940-1942 (rektor), Alojzy Lądwik 1942-1943 (rektor), Józef Nęcek 1943-1946 (dyrektor i rektor). Zob. Rozner, Żurek, Salezjanie we Lwowie, s. 379.

${ }^{23}$ Oratorium salezjańskie - historycznie pierwsza i wyróżniająca się forma salezjańskiego duszpasterstwa młodzieżowego, rodzaj współczesnej i rozbudowanej świetlicy młodzieżowej. Z formy oratoryjnej ks. Bosko nie zrezygnował, mimo że już za jego życia salezjanie prowadzili różnego rodzaju szkoły, bursy, sierocińce i parafie. Priorytet oddziaływania oratoryjnego jednoznacznie określały konstytucje zgromadzenia. 
stowarzyszeń religijnych. Kolejną formą pracy było duszpasterstwo młodzieżowe wedle charyzmatu salezjańskiego obejmujące katechizację, działalność oratorium młodzieżowego oraz młodzieżowych stowarzyszeń religijnych. Trzecim polem działalności było duszpasterstwo związane z sanktuarium Matki Boskiej Ostrobramskiej, w którym organizowano i świętowano uroczystości religijne, patriotyczne i wojskowe. Większe uroczystości reoligijne i patriotyczne w mieście połączone z nabożeństwem odbywały się w kościele salezjańskim ${ }^{24}$.

Żywotnym przejawem oddziaływania duszpasterskiego przy tym kościele wotywnym był kult Najświętszej Maryi Panny. Kościół łyczakowski był sanktuarium ku czci Matki Boskiej Ostrobramskiej Królowej Polski. Centralnymi świętami maryjnymi były odpusty odprawiane 16 listopada w święto Matki Boskiej Ostrobramskiej oraz 24 maja w święto Matki Bożej Wspomożycielki Wiernych. Uroczystości odpustowe poprzedzone były odprawianą nowenną, a w jej trakcie uroczystym triduum i 40-godzinnym nabożeństwem. W kościele tym Maryja była czczona także pod wezwaniem Wspomożenia Wiernych, gdyż była on główną patronką zgromadzenia. Dnia 24 każdego miesiąca odprawiana była Msza Święta $\mathrm{w}$ intencji salezjanów, młodzieży, pomocników salezjańskich ${ }^{25}$, dobrodziejów zgromadzenia i poszczególnych placówek. Po Mszy Świętej odprawiano nabożeństwo eucharystyczne z litanią loretańską, aktem ofiarowania się Maryi Wspomożycielce, zakończone błogosławieństwem Najświętszym Sakramentem ${ }^{26}$.

Dla formacji duchowej i religijnej wiernych przy kościele ostrobramskim działały stowarzyszenia kościelne i świeckie: Związek Pomocników Salezjańskich, Arcybractwo Straży Honorowej Najświętszego Serca Pana Jezusa, Stowarzyszenie św. Wincentego a Paulo (oddział męski i żeński), Bractwo Różańcowe, Koło Rodzicielskie i chór przykościelny.

Dnia 12 III 1935 roku w sali Sokoła IV odbyło się spotkanie obywatelskie, w którym uczestniczyli duchowni i świeccy Lwowa, na czele z abpem Twardowskim i ks. prałatem Władysławem Librewskim. Przełożony domu i rektor kościoła ks. Jan Świerc wygłosił referat na temat życia i działalności św. Jana Bosko, działalności zgromadzenia salezjańskiego oraz mówił o celu i zadaniach Związku Pomocników Salezjańskich. Na wezwanie prałata Librewskiego wszyscy uczestnicy zebrania zgłosili akces do tego Związku. Jego członkowie odbywali regularne spotkania $\mathrm{z}$ tematyczną konferencją $\mathrm{w}$ każdą drugą niedzielę miesiąca przed nieszporami niedzielnymi. Z zachowanej listy członków wynika, że do Związku należało 156 osób. Oprócz osobistej formacji wewnętrznej przy salezjańskiej placówce pomocnicy wspólnie z salezjanami organizowali festyny, zabawy, loterie

${ }^{24}$ W.W. Żurek, Salezjanie w archidiecezji lwowskiej 1904-2012, w: W mocy Ducha Świętego. Księga pamiątkowa Jego Ekscelencji Księdza Biskupa Edwarda Białogłowskiego z okazji XXV rocznicy święceń kaptańskich, red. P. Mierzwa, M. Nabożny, Rzeszów 2013, s. 478.

${ }^{25}$ Pomocnicy Salezjańscy (obecnie Współpracownicy Salezjańscy) byli tercjarzami Towarzystwa Salezjańskiego. Pierwotnie członkami tego związku byli duchowni i świeccy, obecnie świeccy. Ich celem i zadaniem jest uświęcenie własnej duszy oraz wspieranie możliwymi środkami i sposobami ubogą młodzież i salezjanów pracujących na tym polu. Krawiec, Powstanie Towarzystwa św. Franciszka Salezego, s. 73.

${ }^{26}$ Rozner, Żurek, Salezjanie we Lwowie, s. 386. 
fantowe, z których dochód przeznaczano głównie na dokończenie wystroju wnętrza kościoła. W intencji żyjących członków Związku była odprawiana Msza Święta w każdy 24. dzień miesiąca. Za zmarłych członków sprawowano Eucharystię w wigilię liturgicznej uroczystości św. Jana Bosko (31 stycznia) ${ }^{27}$.

Arcybractwo Straży Honorowej Najświętszego Serca Pana Jezusa przy kościele łyczakowskich powstało 16 II 1938 roku. Jego celem było praktykowanie i szerzenie kultu eucharystycznego. Dyrektorem arcybractwa został ks. Jan Podkul. Z inicjatywy dyrektora członkowie ufundowali własny sztandar, który 3 lipca tego roku poświęcił ks. prałat Albin Warszylewicz. Pół roku później do Straży Honorowej należało 136 członków. Ich spotkania odbywały się w każdy pierwszy piątek miesiąca po nabożeństwie wieczornym ${ }^{28}$.

Stowarzyszenie św. Wincentego a Paulo - oddział żeński zawiązało się w listopadzie 1937 roku. Jego członkinie skupiały się na pracy na rzecz najuboższych dzielnicy Górny Łyczaków, m.in. na Wielkanoc 1938 roku urządziły tzw. święcone, obdarowując nim 30 rodzin będących pod ich stałą opieką, po uprzednim odebraniu od nich kartek z odbytej spowiedzi wielkanocnej. Oddział męski tego Stowarzyszenia podobną akcją w tym roku objął 60 najuboższych rodzin dzielnicy. Okazją do pełnienia dzieł miłosierdzia chrześcijańskiego były „Tygodnie Miłosierdzia" organizowane $\mathrm{w}$ adwencie $\mathrm{i} \mathrm{w}$ wielkim poście. W czasie ich trwania przeprowadzano zbiórki pieniędzy, żywności i ubrań dla ubogich oraz organizowano loterie fantowe z myślą o pomocy potrzebującym. W czasie II wojny światowej przy domu salezjańskim na Górnym Łyczakowie prowadzona była kuchnia ludowa dla ubogich ${ }^{29}$.

Działalność salezjanów przy kościele łyczakowskim koncentrowała się na wychowaniu dzieci i młodzieży. Celem przełożonych tej placówki było wybudowanie zakładu wychowawczego, szkoły rzemiosł i bursy. Generał Zgromadzenia, erygując we Lwowie dom zakonny, określił, że do jego działalności ma należeć m.in. prowadzenie świątecznego i codziennego oratorium męskiego. Inicjatorem i kierownikiem oratorium był od 1934 roku ks. Ludwik Mroczek. Oratorianie zostali podzieleni na sekcje, z których najbardziej aktywna była sekcja ministrancka i koło autorskie. Kierownictwo oratorium promowało współzawodnictwo między sekcjami, co pobudzało u chłopców ducha gorliwości i entuzjazmu. Wkrótce dla potrzeb oratorium wydzierżawiono od gminy miasta stający w pobliżu kościoła budynek przyrogatkowy przy ul. Łyczakowskiej 148. Jego poświęcenia dokonał 9 IV 1935 roku proboszcz parafii św. Antoniego ks. kanonik Walenty Dubiel. Przejawem rozwoju oratorium było powołanie przez jego kierownika ks. Ludwika Mroczka Koła Przyjaciół Oratorium Salezjańskiego, z własnym zarządem: prezes, przewodniczący, sekretarz, skarbnik. Na co dzień członkowie Koła pełnili dyżury w oratorium, dostarczali niezbędnych środków, sprzętu, gier, strojów ministranckich. Koło Przyjaciół odpowiedzialne było za stan finansowy oratorium. Głównym źródłem dochodów były ofiary z deklaracji członkowskich i z wystawianych sztuk teatralnych przygotowywanych przez oratorianów. Dla przy-

\footnotetext{
27 Tamże, s. 387-388.

28 Tamże, s. 389.

${ }^{29}$ Tamże, s. 389-390.
} 
kładu - w roku szkolnym 1935/1936 wystawiono 6 sztuk teatralnych. Kolejny kierownik (od 1936 roku) ks. Emanuel Słodczyk zorganizował orkiestrę oratoryjną i w szczególny sposób zadbał o teatr, m.in. przez zakup ludowych strojów mazurskich, szlacheckich, góralskich i płaszczy królewskich. Z grona oratorianów powołano Straż Honorową Najświętszego Serca Pana Jezusa. Oratorium salezjańskie było czynne także w wakacje dla tych chłopców, którzy miesiące letnie spędzali w mieście. Przy oratorium powstała w lutym 1937 roku biblioteka, na początku 1939 roku miała 2600 tomów. Powiększała swój księgozbiór głównie drogą darowizn od osób prywatnych. Czynna była trzy dni w tygodniu. Biblioteka prenumerowała kilkanaście czasopism. Kierownikami oratorium byli: ks. Ludwik Mroczek (1934-1936), ks. Emanuel Słodczyk (od 1936 roku), ks. Jan Podkul, ks. Tadeusz Repich, ks. Józef Czarnecki (1938/1939). Najaktywniejszym okazał się ks. Tadeusz Repich, młody i energiczny salezjanin, nauczyciel religii w Męskiej Szkole Powszechnej im. Zimorowicza nr 63. „Młodzież nie znała innego księdza na Górnym Łyczakowie jak tylko ks. Repicha" (z kroniki oratorium). Za jego kierownictwa prawie wszyscy oratorianie byli uczniami tej szkoły. To on wyegzekwował znajomość przez ministrantów ministrantury oraz wyposażył ich w bogate stroje liturgiczne: komeżki, kapturki i sukienki. Ministrantami było 150 chłopców $^{30}$.

W szkole tej katecheta ks. Tadeusz Repich na początku roku 1937/1938 zorganizował na wzór harcerski Krucjatę Eucharystyczną ${ }^{31}$. Członkowie mieli własny hymn - „Jam rycerz Boga” i zawołanie: „Króluj nam Chryste - zawsze i wszędzie". Do ich obowiązków należała adoracja Najświętszego Sakramentu w kościołach ojców jezuitów (ul. Jabłonowskich, ul. Borkowskich), angażowali się w organizację procesji Bożego Ciała, a uczestnicząc w niej w bogatych strojach ze sztandarami i proporczykami, budzili powszechne uznanie i zachwyt. Posiadali własny sztandar, który 8 XII 1937 roku w uroczystość Niepokalanej poświęcił jezuita ks. Jan Mayer ${ }^{32}$. Podczas tej uroczystości przyjęto 130 „młodych rycerzy"33.

Główną formą działalności duszpastersko-wychowawczej salezjanów była katechizacja. Według obowiązującego prawodawstwa (Konstytucja marcowa 1921 i Konkordat 1925) nauka religii była obowiązkowe w szkołach podstawowych i średnich. Salezjanie uczyli w Męskiej Szkole Powszechnej im. Zimorowicza oraz w szkołach w Krzywczycach i w Pasiekach.

${ }^{30}$ Tamże, s. 390-392.

${ }^{31}$ Do Krucjaty przyjmowano po I Komunii św. Członkowie podzieleni byli na zastępy, których było 12 . Nosili własne odznaki, szarfy i mundurki zaprojektowane przez ks. Repicha: długie peleryny z niebieskiego sukna z emblematami krucjaty oraz sztywne rogatywki.

${ }^{32}$ Mayer Jan (1881-1956) - urodził się we Lwowie, do jezuitów wstąpił w 1898 roku w Starej Wsi, święcenia kapłańskie przyjął w 1911 roku. Pracował jako wychowawcza w Chyrowie 19121913, 1914-1916, w Zakopanym 1925-1926, Lwowie 1926-1928. Następnie pełnił funkcję sekretarzy prowincjałów. Pracował w domu w Krakowie, Czechowicach, Zakopanem, Lwowie i Krakowie. Encyklopedia wiedzy o jezuitach na ziemiach Polski i Litwy 1564-1995, red. L. Grzebień, Kraków 1996, s. 413.

${ }^{33}$ Rozner, Żurek, Salezjanie we Lwowie, s. 392-393. 


\section{Lata II wojny światowej i rzeczywistość powojenna}

Po wybuchu II wojny światowej i agresji sowieckiej 17 IX 1939 roku na Polskę dwaj agresorzy podzielili między siebie ziemie polskie. Śląsk, Wielkopolskę, Pomorze, Mazowsze i Mazury Niemcy włączyli do III Rzeszy, a z pozostałych terenów przez nich zajętych utworzyli Generalną Gubernię. Tereny na wschód od Pisy, Narwi, Bugu i Sanu Sowieci włączyli do Ukraińskiej i Białoruskiej Socjalistycznej Republiki Radzieckiej. Niemcy do Lwowa wkroczyli 13 IX 1939 roku, a już 19 września weszły oddziały sowieckie od strony rogatki łyczakowskiej, dokonując ostrzału kościoła salezjańskiego. Rozpoczęły się aresztowania pojedynczych osób i grup ${ }^{34}$.

Dom salezjański na Górnym Łyczakowie stał się jedynym miejscem oparcia dla salezjanów wypędzonych przez Sowietów z Drohowyża k. Mikołajewa ${ }^{35}$, Daszawy k. Stryja ${ }^{36}$ i Zakładu im. Abrahamowiczów we Lwowie ${ }^{37}$. Na początek zgłosiło się do domu na Górny Łyczaków około 50 salezjanów, głównie kleryków. Ponieważ parterowy budynek nie mógł pomieścić wszystkich, wynajmowano mieszkania w domach prywatnych. W jesieni 1939 roku niektórzy przedostali się na Węgry, inni do Generalnej Guberni, kilku zostało wcielonych do armii sowieckiej i ślad po nich zaginął.

W tym czasie nabożeństwa w kościele ostrobramskim odbywały się bez większych trudności. Od końca października 1939 roku do maja 1940 roku przy kościele prowadzono normalne duszpasterstwo parafialne oraz prowadzono księgi metrykalne chrztów, małżeństw i pogrzebów. Jednak życie mieszkańców w okupowanym mieście stawało się coraz trudniejsze. Najtrudniejsze było zdobycie chleba i opału. Na kościół władze sowieckie nałożyły podatki, które salezianie uiszczali dzięki ofiarności lwowian. Dnia 15 II 1940 roku przez stację kolejową na Łyczakowie przeszedł pierwszy transport Polaków na Syberięę

${ }^{34}$ Dnia 23 IV 1940 roku został aresztowany dyrektor ks. Antoni Guzik. Po rocznym więzieniu we Lwowie w kwietniu 1941 roku został zesłany do obozu na Syberię. Zob. Nekrolog salezjanów polskich 1891-1976, opr. J. Długołęcki, A. Świda, Kraków-Łódź 1974, s. 37-38.

${ }^{35}$ W sierpniu 1939 roku salezjanie przejęli kierownictwo Zakładu Fundacji hr. Stanisława Skarbka w Drohowyżu k. Mikołajewa. Krótki czas salezjanie opiekowali się chłopcami. Już w październiku 1939 roku otrzymali od nowych władz nakaz opuszczenia zakładu i zmuszeni byli wyjechać do Lwowa. Zob. Świda, Towarzystwo Salezjańskie, s. 185.

${ }^{36}$ W Daszawie w archidiecezji lwowskiej salezjanie otwarli w 1904 roku drugi po Oświęcimiu dom zakonny - nowicjat salezjański, nieco później także dom studiów filozoficznych, a od 1907 roku funkcjonowało tam niższe seminarium duchowne i prowadzono duszpasterstwo. Taki charakter pracy salezjanie prowadzili w Daszawie do 1939 roku. Zob. A. Świda, Salezjańskie szkolnictwo $w$ Polsce (zarys), w: 75 lat działalności salezjanów w Polsce. Ksiegga pamiatkowa, red. R. Popowski, S. Wilk, M. Lewko, Łódź-Kraków 1974, s. 50.

${ }^{37}$ Zakład im. Abrahamowiczów zamienili Niemcy na szkołę milicji ukraińskiej. Na przełomie lipca i sierpnia 1944 roku ks. Józef Nęcek wystąpił do władz sowieckich o zwrot budynku zakładu. Odmowna odpowiedź nie pozostawiała złudzeń nie tylko co do tej sprawy, ale i przyszłości Lwowa. Zob. W. Żurek, Salezjańskie szkolnictwo ponadpodstawowe w Polsce 1900-1963. Rozwój i organizacja, Lublin 1996, s. 245-246.

${ }^{38}$ J. Ślósarczyk, Historia Prowincji świętego Jacka Towarzystwa Salezjańskiego w Polsce, 
Ogromną zasługą rektora kościoła ks. Jan Symiora było zainicjowanie w podziemiach kościoła kuchni ludowej dla biednych rodzin polskich. W produkty zaopatrywała kuchnię Rada Główna Opiekuńcza ${ }^{39}$ - Oddział Lwów, która przez cały okres wojny we wszystkich kościołach w niedziele organizowała zbiórki pieniężne. Organizowano „Tygodnie Miłosierdzia”, prowadzono sprzedaż święconych ziół, organizowano okazjonalne imprezy ${ }^{40}$. W kuchni pracowały siostry serafitki. Przy kuchni zawiązał się komitet, który za kolejnego rektora kościoła ks. Alojzego Lądwika przejął w 1942 roku zarząd nad kuchnią ${ }^{41}$. Miesięcznie wydawano do 400 obiadów (maj 1943). Kuchnia ludowa funkcjonowała jeszcze po zakończeniu wojny, niosąc pomoc biednym w sytuacji, kiedy tego najbardziej potrzebowali.

W czasie walk o Lwów w wojnie niemiecko-rosyjskiej w czerwcu 1941 roku Rosjanie bombardowali wieżę kościelną, która była dla Niemców ważnym punktem obserwacyjnym i nawigacyjnym. Tylko 27 czerwca spadło w pobliżu kościoła 12 bomb, z których jedna uderzyła w dach kościoła. Władze niemieckie zwolniły kościół z dotychczasowych podatków. Dozwolona była katechizacja w szkołach. Nie udało się odzyskać lokali poprzednio zajmowanych do pracy z młodzieżą, gdzie planowano zorganizować sierociniec. Po ustaniu walk przystąpiono do usuwania szkód i naprawy uszkodzeń. Salezjanie współpracowali z duchowieństwem parafialnym, a rektor kościoła ks. Jan Symior pełnił obowiązki proboszczowskie z możliwością udzielania chrztów, ślubów i pogrzebów, jednak za każdym razem akta i księgi metrykalne przekazywał do kancelarii parafii św. Antoniego $0^{42}$.

Dnia 22 VII 1944 roku wojska sowieckie stanęły na przedmieściu Lwowa i rozpoczęły się walki o miasto. Następnie Sowieci wprowadzali w życie układ z PKWN z 9 IX tego roku w sprawie przesiedlenia Polaków i Żydów z Zachodniej Ukrainy (USRR) do Polski i Ukraińców z Polski. Ten exodus odbywał się w bardzo dramatycznych i bolesnych okolicznościach. Tak zwaną repatriację miał przeprowadzać komitet utworzony przez Komunistyczny Związek Patriotów Polskich. Do tego komitetu mieli wejść także duchowni. Na ośmiu wytypowanych księży

t. 3: Wojna 1939-1945, Pogrzebień 1966, s. 280 (mps, Archiwum Salezjańskiej Prowincji Krakowskiej).

${ }^{39}$ Rada Główna Opiekuńcza - polska organizacja charytatywna działająca w czasie obu wojen światowych. Działała od lutego 1940 do stycznia 1945 roku za zgodą gubernatora Hansa Franka. Działalność Rady wspierał abp Adam Sapieha. Z pomocy RGO korzystało ok. 700-900 tysięcy osób rocznie.

${ }^{40} \mathrm{~Np}$. 16 I 1943 roku odbył się dobroczynny koncert kolęd zjednoczonych chórów miasta oraz chóru kościoła Matki Boskiej Ostrobramskiej na wsparcie funduszu kuchni. Zob. Rozner, Żurek, Salezjanie we Lwowie, s. 402.

${ }^{41}$ Komitet usunął z pracy w kuchni siostry serafitki pod zarzutem okradania magazynu. Ta sytuacja nabrała cech skandalu. Prace komitetu krytycznie oceniała kuria arcybiskupia i osoby prywatne. Niestety, ks. Lądwik bronił stanowiska komitetu. Dopiero jego następca (od sierpnia 1943 roku) ks. Józef Nęcek przywrócił porządek po wykryciu nadużyć w prowadzeniu kuchni przez komitet. Zob. Rozner, Żurek, Salezjanie we Lwowie, s. 402; J. Nęcek, Wspomnienia 1916-1972, Jeleń-Jaworzno 8 b.r.w., s. 91 (mps, Archiwum Salezjańskiej Inspektorii Krakowskiej).

${ }^{42}$ Ślósarczyk, Historia Prowincji, t. 3, s. 290. 
abp Eugeniusz Baziak zezwolił tylko trzem: ks. Tadeuszowi Załuczkowskiemu (proboszcz św. Elżbiety), wikariuszowi z Lewandówki i ks. Józefowi Nęckowi z Górnego Łyczakowa. Niestety, ten komitet nigdy nie został zaangażowany do repatriacji ${ }^{43}$.

Po zajęciu w 1944 roku Lwowa przez wojska sowieckie i ustanowieniu prawodawstwa ukraińskiego zabroniono nauki religii w szkole. Wówczas nauczanie religii zorganizowano w kościele łyczakowskim w kaplicy Najświętszego Serca Pana Jezusa i u sióstr serafitek (ul. Piątaków 5). Salezjanie katechizowali polskie dzieci ze szkół im. Zimorowicza (żeńskiej i męskiej). W nowych warunkach frekwencja znacznie spadła, np. w szkole męskiej z klasy IV uczęszczał jeden uczeń, a z klasy VI żaden. Prowadzono także naukę religii dla młodzieży szkoły średniej w zakrystii kościoła. Przygotowanie dzieci i młodzieży do I Komunii św. odbywało się w przeciągu miesiąca i organizowane było kilka razy w roku, np. w kwietniu 1945 roku zgłosiło się 110 dzieci, a w lipcu tego roku odwołano przygotowanie, gdyż zapisał się tylko jeden chłopiec. Podobnie było z przygotowaniami do sakramentu bierzmowania, które przeprowadzano w kościele salezjańskim. Do tego sakramentu młodzież przystępowała w kościele parafialnym św. Antoniego po przedstawieniu zaświadczenia z kościoła łyczakowskiego ${ }^{44}$.

Zmiany polityczne po II wojnie światowej spowodowały, że prawie całe terytorium archidiecezji lwowskiej włączono do ZSRR, oprócz dekanatu bełskiego, lubaczowskiego i częściowo żółkiewskiego. Od początku 1945 roku rozpoczęły się w mieście aresztowania znaczniejszych obywateli polskich, zarówno duchownych, jak i świeckich. Placówkę na Górnym Łyczakowie opuścili do lata 1945 roku wszyscy salezjanie z wyjątkiem ks. Nęcka ${ }^{45}$. Starał się on kontynuować normalne duszpasterstwo dzięki pomocy ks. Józefa Michałka, który przeprowadził się do sióstr Sacré Coeur na Łyczakowie, oraz ks. Zygmunta Szelążka. Naukę religii prowadzono tylko w kościele lub u sióstr serafitek. Od 1946 roku wyjeżdżały transporty duchownych „na zachód”. Salezjanom wyznaczono dzień 4 czerwca, w transporcie trzecim. Wcześniej ks. Nęcek wysyłał okazyjnie do salezjańskiej kurii prowincjalnej w Krakowie mienie z kościoła ostrobramskiego. Przed wyjazdem urzędnicy dokonali spisu przedmiotów. W ostatnią niedzielę przed wyznaczonym terminem odprawiono Mszę Świętą zbiorową w intencji wszystkich mieszkańców Górnego Łyczakowa, zarówno wyjeżdżających, jak i pozostających, z prośbą o opiekę Mati Boskiej Ostrobramskiej, Matki Miłosierdzia. Na dzień następny ogłoszono ostatnie nabożeństwo i przekazanie kluczy do Izby Skarbowej. To nabożeństwo w kościele ostrobramskim tak opisał ks. Nęcek:

„Od wczesnego rana paliły się w kościele wszystkie świece, lampy, zacheuszki. Wystawienie Najświętszego Sakramentu trwało do 6 rano. Odprawili Msze św.: ksiądz Szelążek, ksiądz Michałek i ja ostatnią. Rozdałem na niej Komunię świętą i wypuryfikowałem naczynia liturgiczne. Po nabożeństwie Hostię z monstrancji spożyła siostra Elżbietanka. Ludzie nie chcieli rozstawać się ze swą uko-

${ }^{43}$ M. Leszczyński, Archidiecezja lwowska obrządku tacińskiego w granicach Polski 19441992, Lublin 2011, s. 25-26, 28.

${ }^{44}$ Rozner, Żurek, Salezjanie we Lwowie, s. 400-401, 404.

${ }^{45}$ Żurek, Oddziaływanie duszpasterskie salezjanów, s. 409. 
chaną świątynią. Wstrząsająca była chwila, gdy mistrz murarski, staruszek 80letni, który 10 lat temu przedtem wmurowywał Relikwie święte do ołtarza, teraz donośnie uderzył młotem, ażeby te Relikwie wyjąć (...). Nie szło łatwo, bo ołtarz z jednego kamienia (...) po całym kościele rozlegał się łomot młota i szloch wiernych, którzy całowali mury kościoła, ołtarze, żegnali się z pochowanym tam Arcybiskupem, a potem $\mathrm{z}$ nami. Odtąd dla katolików miasta miał służyć jedynie kościół katedralny"46.

Dnia 5 czerwca ks. Nęcek przybył do Przemyśla. Tam spotkał się z abpem Baziakiem. Po wakacjach otrzymał nominację na dyrektora Niższego Seminarium Duchownego w Marszałkach. Do Marszałek przewieziono także archiwum dwóch domów lwowskich (z Górnego Łyczakowa i Zakładu Fundacji Abrahamowiczów) i przedmioty stamtąd pochodzące, a czasowo złożone w Przemyślu i w Krakowie ${ }^{47}$.

\section{Zakład wychowawczy na Górnym Lyczakowie - pomnik XX-lecia Obro- ny Lwowa}

Warunkiem przekazania kościoła Matki Boskiej Ostrobramskiej salezjanom było wybudowanie zakładu wychowawczego dla biednej młodzieży. Pierwotnie zamierzano budować kościół i zakład równocześnie. Ekonomia zdecydowała, że jedynie zdołano zakupić sąsiadujący z kościołem plac pod budowę zakładu, co i tak w ogromnym stopniu naruszyło finanse inwestycji kościelnej na Łyczakowie $^{48}$.

Dopiero zapowiadane na 1938 rok obchody 20-lecia obrony Lwowa urealniały rozpoczęcie budowy zakładu. W czasie uroczystości w świątyni wotywnej za wyzwolenie miasta w 1918 i 1920 roku dnia 3 V 1938 roku mieszkańcy Lwowa złożyli wota i ślubowanie przed obrazem Matki Miłosierdzia. W lipcu 1938 roku Związek Obrońców Lwowa i organizator uroczystości majowych zdecydował upamiętnić 20. rocznicę obrony Lwowa wybudowaniem przy kościele ostrobramskim „Żywego Pomnika”: salezjańskiej szkoły rzemieślniczej i bursy dla biednej młodzieży. Ukonstytuowany Tymczasowy Komitet Organizacyjny wydał we wrześniu tego roku odezwę do rodaków. Pod tą odezwą podpisali się: metropolita lwowski ob. łac. abp Twardowski, prezydent miasta Stanisław Ostrowski, wiceprezydent Franciszek Irzyk, przełożony domu salezjańskiego i rektor kościoła ks. Antoni Guzik i inni. Jeszcze w tym miesiącu odbyło się na Łyczakowie kilka spotkań na temat planu budowy, programu nauczania rzemieślniczego w szkole i spraw z tym związanych. Na początku października 1938 roku ukonstytuował się Komitet Obywatelski Budowy Zakładów Salezjańskich we Lwowie na Górnym

${ }^{46}$ Rozner, Żurek, Salezjanie we Lwowie, s. 402-405.

${ }^{47}$ Niektóre z przywiezionych ze Lwowa przedmiotów przekazano do placówek salezjańskich w Kopcu k. Częstochowy (dom nowicjacki), do Krakowa (dom seminaryjny), Ostrzeszowa (zakład), Kielc (zakład i parafia) i Wrocławia, gdzie ks. Nęcek w kościele Najświętszego Serca Pana Jezusa pozostawił sztandary kościelne i obraz z głównego ołtarza kościoła łyczakowskiego. Zob. Świda, Towarzystwo Salezjańskie, s. 196, 197; tenże, Inspektorzy polskich prowincji, s. 137-138.

${ }^{48}$ Żurek, Oddziaływanie duszpasterskie salezjanów, s. 409. 
Łyczakowie. Komitet miał swą siedzibę we Lwowie przy ul. Solikowskiego $1^{49}$.

Ważne dla realizacji planu budowy zakładu salezjańskiego było zebranie 3 XI 1938 roku Komitetu Obywatelskiego na Górnym Łyczakowie i kolejne zebranie obywatelskie w ratuszu miejskim dnia 14 listopada tego roku, na którym ukonstytuował się Komitet Wykonawczy Budowy „Żywego Pomnika” im. XX-lecia Obrony Lwowa. W jego skład weszło 70 osób. Powołano trzy sekcje: techniczną, prasowo-propagandową i finansową oraz 12-osobową komisję rewizyjną. Zdecydowano ustanowić stały patronat nad przyszłymi zakładami na prawach stowarzyszenia z własnym statutem i zarejestrować stowarzyszenie w Urzędzie Wojewódzkim we Lwowie. Zaczęto też zbierać konieczne środki finansowe na budowę.

Autorem budowlanego projektu zakładu został inż. architekt Duchnowicz, który na spotkaniu komisji technicznej Komitetu Wykonawczego 3 II 1939 roku określił czas wykonania planu na koniec maja tego roku. Po jego zatwierdzeniu chciano rozpocząć budowę w lipcu, a do zimy zakończyć w stanie surowym. Poproszono salezjanów o wyrażenie opinii na temat planu i wydanie zgody na jego realizację. Zauważone przez salezjanów braki miały zostać uwzględnione przy sporządzaniu planu szczegółowego. Na spotkaniu komisji 10 II 1939 roku projekt bursy pod względem architektonicznym oceniono pozytywnie. Na ostatni dzień maja zaplanowano poświęcenie tzw. pierwszej łopaty i rozpoczęcie prac budowlanych. Poświęcenia tego dokonał bp Eugeniusz Baziak w obecności rektora kościoła ks. Antoniego Guzika i przedstawicieli Komitetu Budowy ${ }^{50}$.

Zakład Salezjański „Żywy Pomnik” XX-lecia Obrony Lwowa planowany był jako trzyletnia męska niższa szkoła rzemiosł z bursą dla uczniów po ukończonej szkole powszechnej. Miała prowadzić warsztaty: samochodowy, mechaniczny, ślusarski, stolarski. Jej absolwenci winni posiąść teoretyczną i praktyczną umiejętność prowadzenia warsztatu remontowego maszyn, z uwzględnieniem remontu i obsługi samochodów, motocykli i maszyn rolniczych. W czasie nauki praktycznej uczniowie mieli wykonać komplet narzędzi, który mogli zabrać ze sobą po ukończeniu nauki, a to miało im ułatwić organizowanie przyszłego warsztatu. W szkole miało być 160 uczniów, a w bursie 120 interntistów. Klasy planowano w dwóch oddziałach ${ }^{51}$.

Po wykonaniu prac przygotowawczych Komitet Budowy zwrócił się 22 VIII 1939 roku do III Wydziału Zarządu Miejskiego we Lwowie o wydanie zezwolenia na rozpoczęcie budowy. Tydzień później Komitet skierował list do sekretariatu porozumiewawczego Polskich Organizacji Społecznych Małopolski Wschodniej we Lwowie z prośbą o pośrednictwo w załatwieniu w Warszawie subwencji na budowę. W liście tym podkreślano zubożenie społeczeństwa i zmniejszenie się ofiarności z powodu „ostatnich przesileń i ciężarów” spadających na Lwów i południowo-wschodnią Rzeczypospolitą ${ }^{52}$.

Ostanie spotkanie Komitetu Budowy odbyło się prawdopodobnie 28 VIII

${ }^{49}$ Rozner, Żurek, Salezjanie we Lwowie, s. 405-407.

50 Tamże, s. 416-418.

${ }^{51}$ Tamże, s. 417-418.

52 ASIK, T. KB, Komitet Obywatelski do Polskich Organizacji Społecznych Małopolski Wschodniej, dnia 27 VIII 1939 r., Lwów. 
1939 roku przy kościele łyczakowskim. Omawiano sprawy związane z zatwierdzeniem wykonanych planów budowy. Wybuch wojny uniemożliwił dalszą realizację założonej inwestycji, a po usunięciu salezjanów ze Lwowa do tej sprawy już nie powrócono ${ }^{53}$.

\section{Powrót salezjanów do Lwowa}

Pieriestrojka zapoczątkowana przez Michaiła Gorbaczowa zmieniała ogólny klimat w Związku Sowieckim, skutkiem czego poszczególne republiki ogłaszały niepodległość. W 1991 roku ogłosiła niepodległość Ukraina. Wierni znów mogli wyznawać wiarę, mimo że w stosunku do Kościoła obowiązywało jeszcze, i do dziś obowiązuje, komunistyczne prawodawstwo. Wielu kapłanów wyjeżdżało do pracy na Wschodzie, w tym i salezjanie z Polski (i nie tylko), gdyż wierni odzyskiwali zabrane w czasach komunizmu świątynie, a odczuwano powszechny brak duszpasterzy. Gdy liczba salezjanów podejmujących pracę w Wschodzie wzrosła, należało stworzyć tam odpowiednie struktury administracji salezjańskiej. Dnia 8 XII 1993 roku powołany został Okręg Wschodni Niepokalanego Poczęcia Najświętszej Marii Panny z siedzibą przełożonego (w randze prowincjała) w Moskwie. Do Okręgu należały placówki salezjańskie z Białorusi, Litwy, Rosji, Ukrainy (obrządku łacińskiego i bizantyjsko-ukraińskiego) ${ }^{54}$, Kazachstanu i Gruzji55.

Kościół wotywny Matki Boskiej Ostrobramskiej we Lwowie przy ul. Łyczakowskiej $175^{56}$ przejęła pod koniec lat osiemdziesiątych ubiegłego stulecia Cerkiew prawosławna. Dopiero w wyniku niełatwych starań kościół łyczakowski ostatecznie otrzymali w 1989 roku salezjanie obrządku bizantyjsko-ukraińskiego. Po przeprowadzeniu koniecznych prac remontowych i odnowieniu świątyni według projektu P. Wasilika erygowana została w 1992 roku na Górnym Łyczakowie greckokatolicka parafia Opieki Przenajświętszej Bogarodzicy (Pokrowy). Proboszczem i przełożonym domu zakonnego pw. Maryi Wspomożycielki Wiernych został ks. Vasyl Sapelak ${ }^{57}$. W pierwszym dziesięcioleciu pracowało tam do pięciu salezjanów, od 2002 roku ich liczba zwiększyła się do dziewięciu. Do lwowskiej placówki zakonnej Maryi Wspomożycielki Wiernych przy ul. Łyczakowskiej należała jako filia placówka w Obroszynie (Obroshyno), gdzie w 1996 roku salezjanie otwarli aspirantat i prenowicjat dla kandydatów do zgromadzenia. Przełożo-

${ }^{53}$ Żurek, Oddziaływanie duszpasterskie salezjanów, s. 409.

${ }^{54}$ Początki bizantyjsko-ukraińskiej gałęzi Zgromadzenia sięgają 1930 roku. W latach $1932-$ 1939 cztery grupy kandydatów ukraińskich udały się do Włoch celem odbycia formacji zakonnej i studiów seminaryjnych. Po wyświęceniu na kapłanów podejmowali pracę wśród wiernych swojej narodowości, głównie w Ameryce Północnej i Południowej. W 1991 roku powrócili na Ukrainę i tu podejmowali pracę pastoralną. Zob. Krawiec, Powstanie Towarzystwa św. Franciszka Salezego.

${ }^{55} \mathrm{~W}$. W. Żurek, Możliwości i formy duszpasterzowania salezjanów w powojennej rzeczywistości na terenach europejskich republik radzieckich, ABMK, 87 (2007) s. 325-326.

${ }^{56}$ W kościele salezjanów we Lwowie po 1946 roku mieścił się magazyn książek, posesję ogrodzono drutem, a przed kościołem postawiono na cokole sowiecki czołg.

${ }^{57}$ W 2003 roku przełożonym domu zakonnego został ks. Eugeniu Nebesnik, proboszczem ks. Basilio Sapelak. Od 2008 roku obie funkcje przejął ks. Andrij Seneiko. Zob. Żurek, Salezjanie $w$ archidiecezji lwowskiej 1904-2012, s. 492. 
nym został tam mianowany, jako wikariusz dyrektora lwowskiego, ks. Vasyl Korol. Ta filia funkcjonowała do $2005 \mathrm{roku}^{58}$.

Przy parafii łyczakowskiej otwarto salezjańskie Oratorium Młodzieżowe im. Dominika Savio, w którym stworzono młodzieży warunki do formacji duchowej, modlitwy, rozrywki i rozwijania zainteresowań. W okresie wakacyjnym w ramach oratorium organizowane są obozy letnie - ,wesołe wakacje" ${ }^{9}$.

Salezjanie lwowscy uzyskali w 2003 roku zezwolenie miejscowych władz na otwarcie Młodzieżowego Centrum Ekumenicznego im. Księdza Bosko, przy Drodze Krzywczyckiej 17 A (otwarli je w 2004 roku). W trzypiętrowym budynku mieści się szkoła zawodowa o specjalnościach: sekretarz kierownika, operator komputerowy, stolarz i producent wyrobów z drewna (stolarstwa artystycznego i rzeźbiarstwa). Pierwszy nabór uczniów odbył się w 2006 roku, po uzyskaniu licencji państwowej. Budynek przeznaczony do edukacji posiada odpowiednie lokale i wyposażenie, urządzenia i maszyny, które otrzymano w darze od salezjanów niemieckich i władz. Obok Centrum została wybudowana pracownia stolarska. Przyjęcie do szkoły odbywa się na podstawie rozmowy kwalifikacyjnej i egzaminu. Nauka jest bezpłatna. Dzień nauki rozpoczyna się apelem i modlitwą. Absolwenci otrzymują dyplom państwowy. W pracy edukacyjnej salezjanom ukraińskim pomagają siostry salezjanki.

Pracujący w Centrum salezjanie stworzyli kolejny dom zakonny, którego pierwszym dyrektorem został ks. Stefan Urban (Słowak), a dyrektorem szkoły w 2003 roku ks. Andrij Seneiko, który od 2005 roku przejął obowiązki przełożonego placówki i dyrektora szkoły ${ }^{60}$.

W 2008 roku zorganizowano Gimnazjum im. bł. Klemensa Szeptyckiego, przy ulicy Khothevycha 16, jako filię domu zakonnego w Centrum Ekumenicznym. Przełożonym domu zakonnego i dyrektorem gimnazjum został ks. Petro Mayba ${ }^{61}$.

Salezjanie ukraińscy we wrześniu 2005 roku otwarli kolejną placówkę w Użgorodzie, która wraz z placówkami lwowskimi należy do erygowanej 15 VIII 2005 roku Delegatury Inspektorialnej Ukrainy pw. Maryi Wspomożenia Wiernych, utworzonej na prośbę współbraci obrząaku ukraińsko-bizantyjskiego z siedzibą we Lwowie.

słowa kluczowe: historia Kościoła, Kresy Wschodnie, salezjanie, historia salezjan w Polsce

\footnotetext{
${ }^{58}$ Tamże, s. 493; Schematyzmy salezjańskie 1996-2005.

${ }^{59}$ Żurek, Oddziaływanie duszpasterskie salezjanów, s. 428.

${ }^{60}$ Tenże, Możliwości i formy duszpasterzowania salezjanów, s. 375.

${ }^{61}$ Tenże, Salezjanie w archidiecezji lwowskiej 1904-2012, s. 492-493.
} 


\title{
THE SALESIAN VOTIVE CHURCH OF OUR LADY OF OSTRA BRAMA IN LVIV: HISTORY AND THE PRESENT DAY
}

\begin{abstract}
Summary
The Metropolitan Archbihop of Lviv of the Latin Rite Bolesław Twardowski (18541944) was the founder and the initiator of the construction of the Church of Our Lady of Ostra Brama in the district of Lviv - Górny Łyczaków. The votive church dedicated to the Mother of Mercy was to be a symbol of gratitude for the return of Lviv and Eastern Galicia to their homeland after years of captivity. Started in 1931, the construction of the church was completed and on 7 October 1934, Archbishop Twardowski consecrated it. After that ceremony, at the residence of the archbishop the votive church was given to the Salesians of the Province of St. Jack in Cracow. The Church of Our Lady of Ostra Brama was a rectoral church in the parish of St. Anthony where the Salesians carried out pastoral ministry until 4 June 1946. In 1989, the church was taken over by the Salesians of the Byzantine-Ukrainian Rite where in 1992, the parish of the Protection of Our Most Holy Lady Theotokos (Pokrov) was erected.
\end{abstract}

Keywords: the history of the Church, Eastern Borderlands, the Salesians, the history of the Salesians in Poland 